\title{
Hosts and vectors of Trypanosoma cruzi discrete typing units in the Chagas disease endemic region of the Paraguayan
}

\section{Chaco}

\author{
NIDIA ACOSTA $^{1}$, ELSA LÓPEZ ${ }^{1}$, MICHAEL D. LEWIS ${ }^{2}$, MARTIN S. LLEWELLYN $^{2}$, \\ ANA GÓMEZ ${ }^{3}$, FABIOLA ROMÁN ${ }^{3}$, MICHAEL A. MILES ${ }^{2}$ and MATTHEW YEO ${ }^{2}$ TH \\ ${ }^{1}$ Departamento de Medicina Tropical, Instituto de Investigaciones en Ciencias de la Salud, Universidad Nacional de \\ Asunción - UNA, San Lorenzo CP 2160, Paraguay \\ ${ }^{2}$ Department of Pathogen Molecular Biology, London School of Hygiene and Tropical Medicine, Keppel Street, London \\ WC1E 7HT, UK \\ ${ }^{3}$ Centro para el Desarrollo de la Investigación Cientifica (CEDIC)/Díaz Gill Medicina Laboratorial/Fundación Moisés \\ Bertoni, Asunción, Paraguay
}

(Received 30 October 2016; revised 16 December 2016; accepted 19 December 2016; first published online 9 February 2017)

\section{SUMMAR Y}

Active Trypanosoma cruzi transmission persists in the Gran Chaco region, which is considered hyperendemic for Chagas disease. Understanding domestic and sylvatic transmission cycles and therefore the relationship between vectors and mammalian hosts is crucial to designing and implementing improved effective control strategies. Here we describe the species of triatomine vectors and the sylvatic mammal reservoirs of T. cruzi, in different localities of the Paraguayan and Bolivian Chaco. We identify the T. cruzi genotypes discrete typing units (DTUs) and provide a map of their geographical distribution. A total of 1044 triatomines and 138 sylvatic mammals were captured. Five per cent of the triatomines were microscopically positive for T. cruzi (55 Triatoma infestans from Paraguay and one sylvatic Triatoma guasayana from Bolivia) and 17 animals (12.3\%) comprising eight of 28 (28.5\%) Dasypus novemcinctus, four of 27 (14.8\%) Euphractus sexcinctus, three of $64(4 \cdot 7 \%)$ Chaetophractus spp. and two of $14(14 \cdot 3 \%)$ Didelphis albiventris. The most common DTU infecting domestic triatomine bugs was $\mathrm{TcV}(64 \%)$, followed by $\mathrm{TcVI}(28 \%)$, TcII $(6 \cdot 5 \%)$ and $\mathrm{TcIII}(1 \cdot 5 \%)$. TcIII was overwhelmingly associated with armadillo species. We confirm the primary role of $T$. infestans in domestic transmission, armadillo species as the principal sylvatic hosts of TcIII, and consider the potential risk of TcIII as an agent of Chagas disease in the Chaco.

Key words: Trypanosoma cruzi, Paraguayan Chaco, triatomine vectors, armadillos, discrete typing units.

\section{INTRODUCTION}

Trypanosoma cruzi is the causative agent of Chagas disease, a neglected human protozoan disease that is estimated to affect approximately six million people, spanning 21 endemic Latin American countries, with 60-80 million at risk of infection (WHO, 2015). Trypanosoma cruzi is genetically heterogenous, infecting a large number of mammal species and transmitted by haematophagous triatomine insect vectors. Nomenclature is historically complicated, but $T$. cruzi is currently subdivided into six subspecific groups, referred to as genetic lineages or discrete typing units (DTUs) and designated TcI to TcVI (Zingales et al. 2012). A cohort of geographically disparate bat trypanosomes, provisionally designated as TcBat, has been shown to share phylogenetically close affiliations with TcI (Marcili et al. 2009a), although more detailed sampling is required to confirm this as a formal taxonomic

* Corresponding author: Department of Pathogen Molecular Biology, London School of Hygiene and Tropical Medicine, Keppel Street, London WC1E 7HT, UK. E-mail: Matthew.Yeo@1shtm.ac.uk group. In a recent review, analysing more than 400 sequences with two mitochondrial $(C y t B$ and $C O I I)$ and one nuclear gene $(G p i)$, authors propose three significant reliable mitochondrial clades, named $\mathrm{mt}$ TcI, $\mathrm{mt}$ TcII and mt'TcIII, instead of seven (Barnabé et al. 2016). Phyloepidemiology and host vector associations of $T$. cruzi are complex, but have been partially resolved (Yeo et al. 2005; Miles et al. 2009; Messenger et al. 2015; Brenière et al. 2016). TcI is widespread through the Americas. This is the major DTU found infecting Didelphis opossums in nature, which is believed to be its most ancestral host. TcI was reported predominating in domestic transmission cycles in northern countries of South America (for example, Colombia and Venezuela) and in Central America (Miles et al. 2009). TcIII and TcIV primarily circulate in sylvatic transmission cycles, the former especially associated with armadillos (Yeo et al. 2005) and the latter with a variety of sylvatic mammal species (Miles et al. 2009). TcIV is a secondary cause of Chagas disease in Venezuela. TcIII is rarely reported from domestic transmission cycles. In contrast, TcII, TcV and TVI predominate in domestic transmission cycles in

Parasitology (2017), 144, 884-898. @ Cambridge University Press 2017. This is an Open Access article, distributed under the terms of the Creative Commons Attribution licence (http://creativecommons.org/licenses/by/4.0/), which permits unrestricted re-use, distribution, and reproduction in any medium, provided the original work is properly cited. 
Southern Cone countries of South America (Miles et al. 2009; Messenger et al. 2015; Brenière et al. 2016). Remarkably, $\mathrm{TcV}$ and $\mathrm{TcVI}$ are known to be natural hybrids derived from genetic exchange between TcII and TcIII in recent evolutionary history and are at present strongly associated with domestic transmission cycles (Zingales et al. 2012; Brenière et al. 2016).

Trypanosoma cruzi infection is considered primarily a zoonosis and as such eradication is not possible. Effective control of Chagas disease is achieved by interrupting vectorial transmission, primarily through residual insecticide-spraying to reduce domestic infestation and also by serological surveillance and interruption of transmission by blood transfusion, organ donation and congenitally (WHO, 2015).

There has been remarkable progress in controlling Chagas in some regions of the Americas. However, the Gran Chaco region, which includes territories of Argentina, Bolivia and Paraguay, is currently considered one of the most difficult regions for effective control and remains highly endemic (Hotez, 2014a). The land area is vast and arid, with a low population density consisting of small widely dispersed communities of low socioeconomic status (Gürtler, 2009). More than 20 ethnic groups live in marginalized conditions with minimal access to health care provisions (Gracey and King, 2009; Hotez, 2014b). Indigenous communities of the Gran Chaco show consistently high seroprevalence of human T. cruzi infection, ranging from 12 to $83 \%$ with local variation (Canese and Brice, 1977; Rojas de Arias et al. 1993; Moretti et al. 2010; Samuels et al. 2013).

Although the success of vector control interventions in some areas of the Chaco has substantially reduced disease incidence, the main challenge is the long-term sustainability, and in particular, entomological surveillance. Reinfestation of treated dwellings, when the residual effect of insecticides decreases, is a common feature especially in areas with peridomestic vectors and/or reinvasion by secondary vectors from the sylvatic environment (Provecho et al. 2014; Gaspe et al. 2015). Other obstacles adversely affecting control in the Chaco include the low efficacy of pyrethroid insecticide spraying on often poorly constructed peridomestic structures in this region (Gürtler et al. 2007; Cécere et al.2013). Of further concern, is the appearance of Triatoma infestans populations resistant to pyrethroid insecticides in localities of northern Argentina and southern Bolivia (Lardeux et al. 2010; Gurevitz et al. 2012). Sylvatic populations of $T$. infestans have been identified in the Chaco and pose a potential risk of reinvasion (Noireau et al. 1997a; Ceballos et al. 2011; Quisberth et al. 2011; Rolón et al. 2011) as do secondary vectors, including Triatoma sordida (Almeida et al. 2000; Damborsky et al. 2001; Feliciangeli et al. 2003; Lauricella et al. 2005); additionally sylvatic mammals are potential reservoirs of infection, and all of these factors may confound effective control. This study ascertains the different triatomine species present in the region, the mammal species infected and the associated circulating T. cruzi DTUs. Through a better understanding of the T. cruzi transmission dynamics we aim to improve control strategies.

\section{MATERIALS AND METHODS}

\section{Fieldwork}

Fieldwork collections were performed from 2002 to 2008, with the objective of obtaining and genotyping new isolates of T. cruzi from triatomine bugs and sylvatic mammals. Isolates obtained in previous surveys (Yeo et al. 2005; Llewellyn et al. 2009, Rojas de Arias et al., manuscript in preparation) were also included to generate a more detailed picture of the distribution of T. cruzi DTUs in the Chaco region.

\section{Study area}

The study area encompasses the Paraguayan Chaco (western region), Bolivian Chaco (southern region) and also three further Paraguayan localities $250 \mathrm{~km}$ northeast of Asunción (San Pedro, San Alfredo and Aguapey), within the Department of San Pedro. Study areas are shown in Fig. 1. In total, data were acquired from 28 localities, 24 Paraguayan and four Bolivian. Of the 24 Paraguayan localities, 21 were situated in the Paraguayan Chaco spanning three departments (Boquerón, Presidente Hayes and Alto Paraguay). Within the Department of Boquerón 12 localities were studied: Betania, Campo Loro, Campo Nuevo, Campo Salado, Cesarea, Galilea, Jerico, Campo Alegre, Casuarina, Jotoisha, Tiberia and Samaria. Within the Department of Presidente Hayes a further eight localities were included: Cerrito, Estancia Salazar, 12 de Junio, 20 de abril, Campo Largo, 10 Leguas, Fischat and Jope. Lastly, the one locality from the third department was Don Anibal ranch. These aforementioned localities have been under epidemiological surveillance by the National Program Control of Chagas since 2001. Further details regarding localization, ethnic group and estimated population size of these communities is shown in Table A1 (Appendix A). The remaining three localities lie within the Department of San Pedro (Fig. 1), in the Southeast Chaco: San Pedro, San Alfredo and Aguapey. Localities from the Bolivian Chaco region, San Antonio, Mora, Cuatro Cañadas and Gutierrez were all from Santa Cruz Department.

Indigenous communities consist of nomadic hunters, gatherers and fishermen with some groups of sedentary farmers from distinct linguistic groups (Rojas de Arias, 2003). Dwellings are typically of low quality, walls constructed of wattle and brick, 


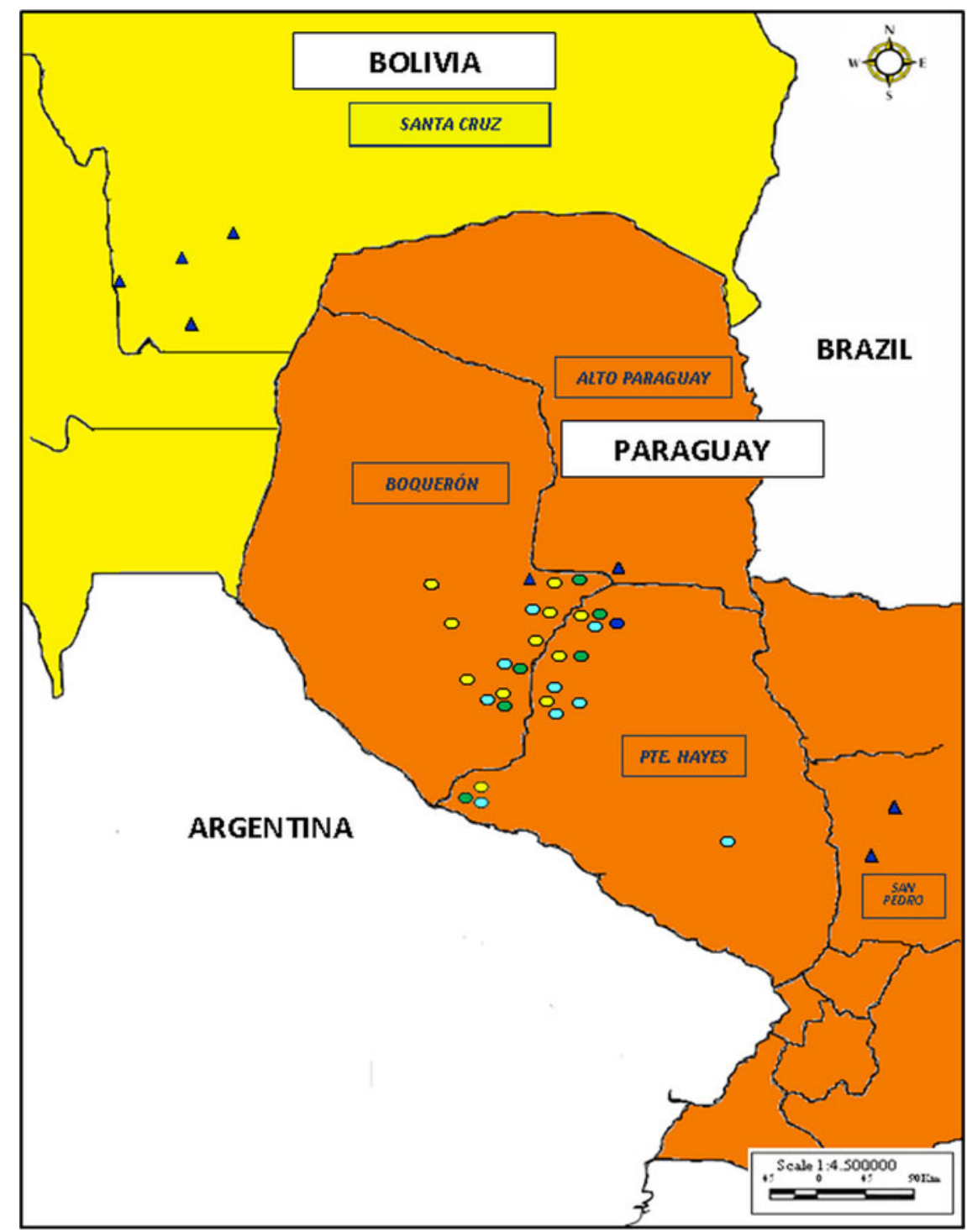

Fig. 1. Distribution of Trypanosoma cruzi DTUs in the study area. Map illustrating study sites in Paraguay (orange) and Bolivia (yellow) and the distribution of trypanosomes characterized. Circles and triangles represent isolates from domestic and sylvatic cycles, respectively. Colours indicate different Trypanosoma cruzi DTUs. Green, TcII; blue, TcIII; yellow, $\mathrm{TcV}$ and light blue, TcVI.

adobe or palm trunk, soil floor with straw, and palm leaves or tin as roofing material. Villages are located in peripheral areas surrounding Mennonite towns. Domestic animals consist primarily of dogs and chickens. Further to the Northeast and in the Bolivian Chaco land use is predominantly for cattle farming and agriculture. To the east of the Paraguayan Chaco, the Department of San Pedro is characterized by more abundant vegetation and intensive agricultural land use.

\section{Collection of triatomine bugs and sylvatic mammals}

Each locality was visited only once. Most of the collection of domiciliary and peridomiciliary triatomines was made by manual searches $(1 \cdot 0$ person hour per house) (Gürtler et al. 1998). Domestic areas inspected included walls, interior side of roofs, furniture and bedding. Peridomestic searches encompassed chicken coups, wood piles and other peridomestic structures (Gurevitz et al. 2011). In Campo Loro, Estancia Salazar and Fischat localities domestic bugs were obtained by the collection of local inhabitants. Sylvatic triatomines were collected by the use of live-bait Noireau traps (Noireau et al. 2000), manual dissection of natural ecotopes (bird nests, fallen trees and scrub) and light traps (Vazquez-Prokopec et al. 2006). Light traps were left overnight and checked in the morning. Captured bugs were placed in labelled containers, the developmental stage noted and identified to the level species by trained personel according to Lent and Wygodzinsky (1979). The captured nymphs were raised in laboratory conditions until they reached the adult stage to confirm the species. Sylvatic mammals were captured by the use of 
Table 1. DTU discrimination based on PCR amplification products (bp) ${ }^{\mathrm{a}}$

\begin{tabular}{llllllll}
\hline \hline PCR reaction & TcI & TcII & TcIII & TcIV & TcV & TcVI & DTU identification \\
\hline 24S $\alpha$ rRNA & 110 & 125 & 110 & $120^{\mathrm{b}}$ & $110 / 125$ & 125 & TcIV, TcV \\
18S rRNA & 160 & 165 & 165 & 155 & 165 & 165 & TcI, TcIV \\
Mini-exon & 350 & 300 & $250^{\mathrm{a}}$ or none $^{\mathrm{c}}$ & $400^{\mathrm{a}}$ or none $^{\mathrm{d}}$ & 300 & 300 & TcI, TcIV, TcIII $^{\mathrm{f}}$ \\
RFLP-PCR $^{\mathrm{e}}$ & 462 & 462 & $314 / 148$ & 462 & $462 / 314 / 148$ & $462 / 314 / 148$ & TcIII $^{(}$(HSP60/EcoRV) \\
\hline \hline
\end{tabular}

a According to Yeo et al. (2005) and Lewis et al. (2009).

b Brisse et al. (2000) reported bands of $125 \mathrm{bp}$ in one strain (Saimiri 3) and of $130 \mathrm{bp}$ for three strains of North American origin. Band of $117 \mathrm{bp}$ was reported by Kawashita et al. (2001).

c According to Brisse et al. (2000). They reported product a low intensity band of $300 \mathrm{bp}$ in two strains (M6241 cl6 and M5631 cl5).

d According to Brisse et al. (2000).

e According to Westenberger et al. (2005) and Lewis et al. (2009).

f Differentiates between TcII and TcVI.

collapsible 'live-traps' including Sherman (H.B. Sherman Trap, Inc., Tallahassee, FL) and Tomahawk (Tomahawk Live Trap Co., WI), baited with a mixture of peanut butter, ripe banana and oats. Ten traps per night were set at approximately $10 \mathrm{~m}$ intervals on animal trails, near burrow entrances, in dense scrub or close to fallen trees. Traps were left in situ for 3 days, set at sunset and examined at dawn, where applicable local hunters were hired to collect live mammals. All specimens captured were sexed, identified to the species level (Neris et al. 2002), and released unharmed after processing (see below).

\section{Isolation and characterization of trypanosomes}

Trypanosomes were obtained from animals via xenodiagnosis and from triatomines by haemoculture and xenoculture as previously described (Miles, 1993). Mammals were first anaesthetized by intramuascular injection using ketamine (Holliday$\mathrm{Scott}^{\circledR}, \quad 50-80 \mathrm{mg} \mathrm{kg}^{-1}$ body weight). Animalhandling procedures were in accordance with the American Society of Mammalogists (Sikes and Gannon, 2011). To excluded the presence of mixed infection biological clones of Trypanosoma cruzi were obtained by direct culture of infected triatomine feces, onto solid medium agar plates, as described previously by Yeo et al. (2007), five clones of each isolate were expanded in culture and DNA extracted [DNeasy kits (QIAGENTM)].

Genetic characterization of DTUs was undertaken using a combination of amplicon profiles from four different polymerase chain reactions (PCR) details of which are shown in Table 1 . Genetic targets were the D7 divergent domain of the 24S $\alpha$ rRNA (Souto et al. 1996), the size variable domain of $18 \mathrm{~S}$ rRNA sequence (Brisse et al. 2000), the non-transcribed spacer of the mini-exon gene (Souto et al. 1996) and the PCR-restriction fragment length polymorphism (PCR-RFLP) of the intergenic region of the heatshock protein 60 (HSP60) gene (Lewis et al. 2009).
Primers and reaction conditions are described in Table B1 (Appendix B). A panel of reference strains, encompassing the known DTUs, was obtained from the London School of Hygiene and Tropical Medicine cryobank repository and consisted of X10 Clone I (DTU TcI), Esmeraldo-cl3 (DTU TcII), Arma 13 (DTU TcIII), CAN III (DTU TcIV), SC43 (D'TU TcV) and CL Brener (D'TU TcVI).

\section{RESULTS}

\section{Triatomines}

A total of 1044 triatomine bugs were included in the current study, 1037 from Paraguay and seven from the Bolivian Chaco. Triatoma infestans $(n=715)$ was found in both domestic and peridomestic environments ( $n=245$ in domestic; $n=470$ in peridomestic) and T. sordida $(n=203)$ only in peridomestic environments (Table 2). Adults, fourth- and fifthinstar nymphs were collected from both species in both areas. In Betania, Campo Salado, Galilea both species shared the same niche in chicken coops. In the localities of Campo Nuevo, Cesarea and Samaria only $T$. sordida was present, while in Estancia Salazar only $T$. infestans was found. Although $T$. infestans was collected from both peridomestic and domestic areas, only domestic specimens were microscopically positive for T. cruzi. Thus, 55 (5.4\%) of T. infestans were positive, including adults $(n=41)$, fourth-instar $(n=10)$ and fifthinstar $(n=4)$ nymphs. Positive triatomines were from the localities of Jerico $(n=31)$, Galilea $(n=2)$, Betania $(n=1)$, Campo Loro $(n=5)$, Estancia Salazar $(n=8)$, Jope $(n=5)$ and Fischat $(n=3)$. In the sylvatic area, 115 of adults $(n=107)$ and nymphs $(n=8)$ of Triatoma guasayana, three adults of $T$. sordida, and one female of Triatoma platensis were captured from the localities of Campo Loro, Don Anibal ranch and Betania respectively and they were microscopically negative. Triatomines obtained from Bolivian Chaco by the cooperation of local inhabitants included seven 
Table 2. Summary table: species captured, location, ecotopes, number of positives and DTUs observed

\begin{tabular}{|c|c|c|c|c|c|c|c|c|c|c|c|}
\hline \multirow[b]{2}{*}{ Country } & \multirow[b]{2}{*}{ Department } & \multirow[b]{2}{*}{ Locality } & \multirow[b]{2}{*}{ Species } & \multirow{2}{*}{$\begin{array}{l}\text { Total } \\
\text { captured }\end{array}$} & \multirow[b]{2}{*}{ Ecotope } & \multirow[b]{2}{*}{ Positive } & \multicolumn{5}{|c|}{ Trypanosoma cruzi DTU } \\
\hline & & & & & & & II & III & V & VI & ND \\
\hline \multirow[t]{41}{*}{ Paraguay } & Boquerón & Betania & Triatoma infestans & 97 & 82 peridomestic 15 Domestic & $1^{\mathrm{a}}$ & & & 1 & & \\
\hline & & & Triatoma sordida & 18 & Peridomestic & - & & & & & \\
\hline & & & Triatoma platensis & 1 & Sylvatic & - & & & & & \\
\hline & & Campo Loro & Triatoma infestans & 5 & Domestic $^{\mathrm{b}}$ & 5 & $1^{\mathrm{c}}$ & & 5 & & \\
\hline & & & Triatoma guasayana & 10 & Sylvatic & - & & & & & \\
\hline & & & Dasypus novemcinctus & 2 & Sylvatic & 2 & & $5^{\mathrm{c}}$ & & & \\
\hline & & & Euphractus sexcinctus & 18 & Sylvatic & 1 & & 1 & & & \\
\hline & & & Chaetophractus spp. & 41 & Sylvatic & 1 & & 1 & & & \\
\hline & & Campo Nuevo & Triatoma sordida & 39 & Peridomestic & - & & & & & \\
\hline & & Campo Salado & Triatoma infestans & 76 & Peridomestic & - & & & & & \\
\hline & & & Triatoma sordida & 40 & Peridomestic & - & & & & & \\
\hline & & Cesarea & Triatoma sordida & 5 & Peridomestic & - & & & & & \\
\hline & & Galilea & Triatoma infestans & 188 & 186 Peridomestic, 2 Domestic & $2^{\mathrm{a}}$ & & & 2 & & \\
\hline & & & Triatoma sordida & 69 & Peridomestic & - & & & & & \\
\hline & & Jerico & Triatoma infestans & 230 & 23 Peridomestic, 207 Domestic & $31^{\mathrm{a}}$ & & & 26 & 1 & 4 \\
\hline & & Campo Alegre $^{\mathrm{e}}$ & Triatoma infestans & - & Domestic & - & & & 3 & & \\
\hline & & Casuarina $\mathrm{e}^{\mathrm{e}}$ & Triatoma infestans & - & Domestic & - & 1 & & 18 & 1 & \\
\hline & & Jotoisha $^{\mathrm{e}}$ & Triatoma infestans & - & Domestic & - & & & 8 & & \\
\hline & & Samaria & Triatoma sordida & 32 & Peridomestic & - & & & & & \\
\hline & & Tiberia $^{c}$ & Triatoma infestans & - & Domestic & & 1 & & & 1 & \\
\hline & Presidente Hayes & Estancia Salazar & Triatoma infestans & 111 & 103 Peridomestic, 8 Domestic & $8^{\mathrm{a}}$ & & & & 4 & 4 \\
\hline & & 12 de Junio $^{\mathrm{e}}$ & Triatoma infestans & - & Domestic & & & & 16 & 21 & \\
\hline & & 20 de brill $^{\mathrm{e}}$ & Triatoma infestans & - & Domestic & & & & & 6 & \\
\hline & & Campo Largo ${ }^{\mathrm{e}}$ & Triatoma infestans & - & Domestic & & 1 & & 6 & & \\
\hline & & 10 Leguas $^{\mathrm{e}}$ & Triatoma infestans & - & Domestic & & & & & 2 & \\
\hline & & Fischat & Triatoma infestans & 3 & Domestic $^{\mathrm{b}}$ & 3 & $3^{\mathrm{c}}$ & & 1 & 1 & \\
\hline & & Jope & Triatoma infestans & 5 & Domestic & 5 & 2 & 2 & 1 & $1^{\mathrm{c}}$ & \\
\hline & & Cerrito & Dasypus novemcinctus & 2 & Sylvatic & - & & & & & \\
\hline & & & Euphractus sexcinctus & 1 & Sylvatic & - & & & & & \\
\hline & & & Chaetophractus spp. & 8 & Sylvatic & - & & & & & \\
\hline & Alto Paraguay & Don Anibal ranch & Triatoma guasayana & 105 & Sylvatic & - & & & & & \\
\hline & & & Triatoma sordida & 3 & Sylvatic & - & & & & & \\
\hline & & & Dasypus novemcinctus & 1 & Sylvatic & - & & & & & \\
\hline & & & Euphractus sexcinctus & 1 & Sylvatic & 1 & & 1 & & & \\
\hline & & & Chaetophractus spp. & 9 & Sylvatic & 1 & & 1 & & & \\
\hline & & & Cabassous spp. & 1 & Sylvatic & - & & & & & \\
\hline & San Pedro & Colonia San Alfredo & Dasypus novemcinctus & 8 & Sylvatic & 1 & & 1 & & & \\
\hline & & & Didelphis albiventris & 2 & Sylvatic & 1 & & & & & 1 \\
\hline & & Aguapey & Dasypus novemcinctus & 6 & Sylvatic & - & & & & & \\
\hline & & & Didelphis albiventris & 12 & Sylvatic & 1 & & & & & 1 \\
\hline & & San Pedro ${ }^{c}$ & Dasypus novemcinctus & - & Sylvatic & - & & 3 & & & \\
\hline
\end{tabular}


sylvatic adult bugs, $T$. sordida (one specimen) and $T$. guasayana (six specimens). One T.guasayana specimen from the locality of Mora was positive.

\section{Sylvatic mammals}

A total of 138 mammals were included in the current study, 26 from the Bolivian Chaco and 112 from Paraguayan localities. From Bolivia animals representing six species were examined, Euphractus sexcinctus ( $n$ $=7)$, Dasypus novemcinctus $(n=9)$, Chaetophractus spp. $(n=6)$, Tamandua tetradactyla (anteaters, $n=1)$, Dasyprocta spp. (agutí, $n=2$ ) and Nasua nasua (coati, $n=1)$. Eight animals (30\%) were found to be infected by haemoculture and/or xenodiagnosis: five $D$. novemcinctus, two E. sexcinctus and one Chaetophractus spp. from Gutierrez and Mora localities.

From Paraguayan localities a total of 112 sylvatic animals of five species were captured and examined. In the Chaco localities, 84 mammals included four different armadillo species: E. sexcinctus $(n=20)$, D. novemcinctus $(n=5)$, Cabassous spp. $(n=1)$ and Chaetophractus spp. $(n=58)$. Six animals $(7 \%)$ from Campo Loro and Don Anibal ranch were infected: two E. sexcinctus, two Chaetophractus spp. and two D. novemcinctus. All the specimens captured in Cerrito were negative by microscopy, xenodiagnosis and haemoculture. Twenty-eight animals were captured from San Pedro. They included $D$. novemcinctus $(n=14)$ and Didelphis albiventris (opossum, $n=14)$. Three animals (11\%) from Colonia San Alfredo and Aguapey, one armadillo and two opossums, were infected.

\section{Trypanosome isolates}

A total of 166 T. cruzi isolates were included in this study, consisting of 63 new field isolates and a further 103 obtained from previous collections, as described below. Table 2 summarizes the origins of the isolates.

Sixty-three isolates were genotyped to DTU; ten from eight triatomines and two Didelphis spp., could not be maintained in culture and were excluded. The isolates from previous collections (Table 2) included 12 that had been genotyped, six from domestic $T$. infestans and six from sylvatic armadillos from the Chaco region of Paraguay (Yeo et al. 2005). Eightythree isolates originated from domestic $T$. infestans (Rojas de Arias et al., in preparation). Eight isolates were from sylvatic armadillos in Bolivia (Llewellyn et al. 2009).

\section{Characterization of trypanosome isolates}

Amplicon sizes obtained with new trypanosome isolates were as expected for the corresponding DTU, according to previous surveys (Yeo et al. 2005; Lewis et al. 2009). Examples for PCR-RLFP 

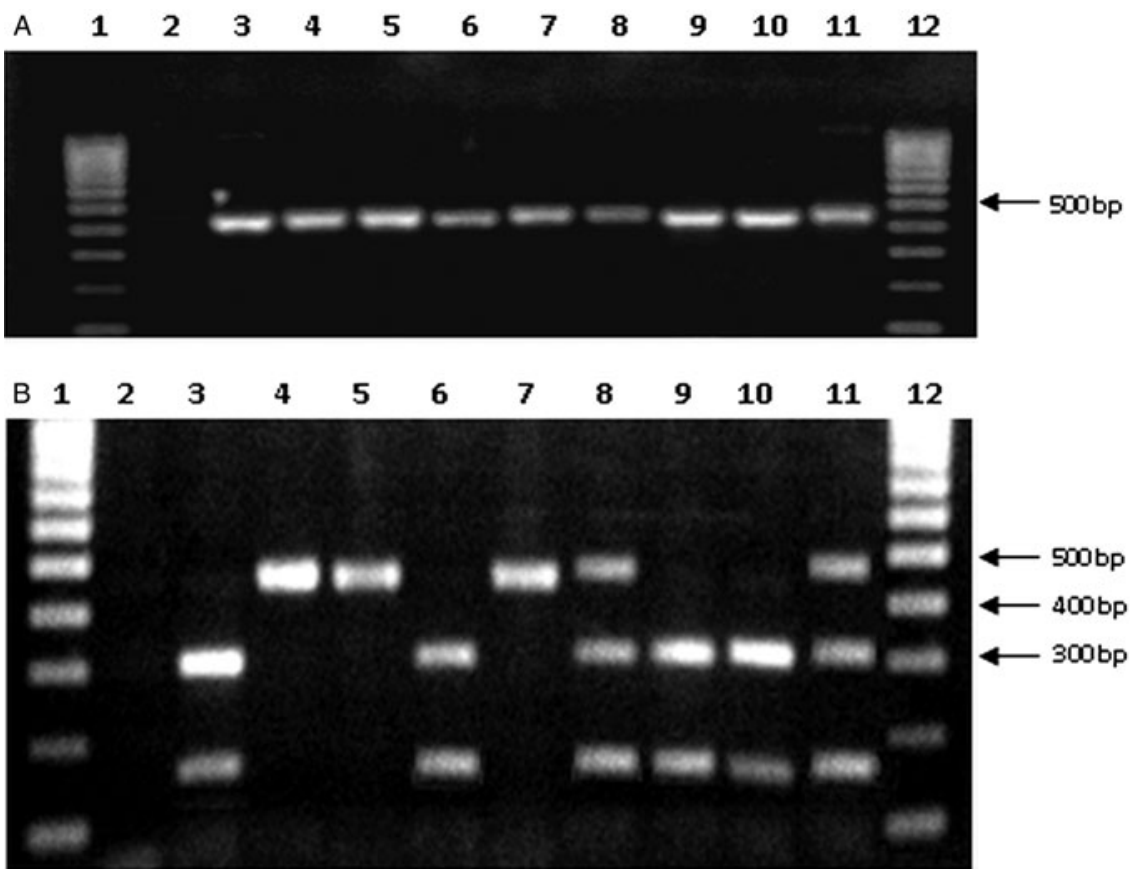

Fig. 2. Agarose gel electrophoresis of PCR-RFLP products from HSP60/EcoRV of selected Trypanosoma cruzi isolates. Samples from sylvatic and domestic hosts in Paraguay and Bolivia: A: products without digestion, B: products after of digestion by EcoRV. Lanes: 1 and 12 contain hyperladder 4; 2: negative control; 3: TcIII from sylvatic Triatoma guasayana in Bolivia; 4-5: TcII from domestic T. infestans in Paraguay; 6-7-8: TcIII, TcII, TcVI reference strains, respectively; 9-10: TcIII from domestic T. infestans in Paraguay; 11: TcVI from domestic T. infestans in Paraguay.

HSP60/EcoRV that differentiate between TcIII, TcII and TcVI are shown in Fig. 2. Domestic $T$. infestans $(n=136)$ were infected with TcII, TcIII, $\mathrm{TcV}$ and TcVI. The most common DTU was $\mathrm{TcV}$ (64\%), followed by TcVI (28\%), TcII (6.6\%) and TcIII (1.5\%). Twenty-nine sylvatic isolates examined from different armadillo species and one T. guasayana (Bolivia) showed an amplicon profile corresponding to DTU TcIII. Five biological clones from each one of the 63 new field isolates were genotyped to detected mixed infections, but none were found.

\section{Spatial distribution of DTUs}

The locality with the most T. cruzi diversity was Jope, with all 4 DTUs circulating in the domestic transmission cycle, followed by Jerico, Casuarina and Fischat with three different D'TUs. DTU distribution in the study areas is shown in Fig. 1 and Table 2. Within the domestic transmission cycle nine isolates of TcII were identified, all originated from $T$. infestans from six Chaco localities: Campo Loro $(n=1)$, Tiberia $(n=1)$, Casuarina $(n=1)$, Jope $(n=2)$, Campo Largo $(n=1)$ and Fischat $(n=3)$. DTU TcV was the most widely dispersed DTU in domestic areas, observed in 11 localities, which were Campo Loro $(n=5)$, Campo Largo $(n=6)$, Jerico $(n=26), 12$ de Junio $(n=16)$, Casuarina $(n=18)$, Fischat $(n=1)$, Jope $(n=1)$, Galilea $(n=2)$, Campo Alegre $(n=3)$, Jotoisha $(n=8)$ and Betania $(n=1)$. Lastly, TcVI was identified in domestic areas of nine localities: Jerico $(n=1)$, Casuarina $(n=1)$, Tiberia $(n=1)$, Estancia Salazar $(n=4)$, 12 de Junio $(n=21), 20$ de abril $(n=6), 10$ Leguas $(n=2)$, Fischat $(n=1)$ and Jope $(n=1)$.

TcIII was predominant among sylvatic isolates and widespread in different armadillo species, including D. novemcinctus $(n=20), E$. sexcinctus $(n=6)$ and Chaetophractus spp. $(n=3)$ from both Paraguay and Bolivia. TcIII was rarely observed in the domestic environment, being found in only two $T$. infestans specimens from the Jope locality of the Paraguayan Chaco. A single sylvatic specimen of $T$. guasayana from Mora locality (Bolivia) also harboured TcIII.

DISCUSSION

\section{Triatomines and mammal species}

Triatomines. Four triatomine species were found in the current study: $T$. infestans $(n=715), T$. sordida $(n=203), T$. guasayana $(n=115)$ and $T$. platensis $(n=1)$. Triatoma infestans was the only species found in the domestic environment and there was no evidence of domiciliation by $T$. guasayana and $T$. sordida. The latter two species were found in peridomestic and/or sylvatic areas. A single specimen of sylvatic $T$. platensis was captured. This presence of $T$. infestans in human dwellings (245 specimens) and peridomestic habitats (470 specimens) confirms 
that it is the primary vector of human T. cruzi infection in the Paraguayan Chaco (Rojas de Arias et al. 1990, 1993, 2011; Zelada et al. 1998; Acevedo et al. 2002). The overall prevalence of $T$. cruzi infection in captured triatomines was $5 \cdot 4 \%$, and all those infected in Paraguay were domestic $T$. infestans. One explanation is peridomestic $T$. infestans feeding on avian blood in chicken coops, and birds cannot maintain T. cruzi infection (Miles et al. 2003). Considering only domestic $T$. infestans the infection rate is $22.4 \%$, representing a substantial risk of transmission to both humans and domestic animals. These findings accord with previous studies in the Paraguayan Chaco, which report human seroprevalence ranging from 12 to $83 \%$, and house infestation rates from 26 to $100 \%$ (Canese and Brice, 1977; Chapman et al. 1984; Rojas de Arias et al. 1993, 2011; Rojas de Arias, 2003). Thus, the Chaco region is the most highly endemic for Chagas disease in Paraguay, primarily among native Amerindians of the low socioeconomic status.

In peridomestic environments, two triatomines species were found ( $T$. infestans and $T$. sordida). Triatoma infestans in peridomestic areas poses a potential risk of re-infestation of buildings if surveillance measures are not continuous. Although peridomestic areas are also insecticide sprayed as part of the national control programme, the residual effect is lower than in the domicile because of exposure to climatic conditions. As a consequence this makes peridomestic bugs more difficult to control, requiring that spraying and surveillance to be more frequent. Triatoma sordida is widely distributed throughout Central Brazil, Eastern and Central Bolivia, the Chaco region of Paraguay and northwestern Argentina where it occurs primarily in the sylvatic environment (Lent and Wygodzinsky, 1979; Diotaiuti et al. 1995). In the Bolivian Chaco, two putative cryptic species belonging to T. sordida complex, named groups 1 and 2, respectively, were recognized circulating in sympatry, using multilocus enzyme electrophoresis (Noireau et al. 1998). This species shows great capacity of adaptation to peridomestic sites, especially in association with chickens (Macchiaverna et al. 2015). In the current study, all specimens $(n=203)$ were negative for flagellates probably because their principal food sources are avian. A primary domiciliation by $T$. sordida in the Chaco region was described in localities of Velasco Province, Department of Santa Cruz (Bolivia), where $16 \cdot 2 \%$ of bugs were found infected by T. cruzi, although the probability of transmission to humans was considered low (Noireau et al. 1997b; Brenière et al. 1998). Three species of sylvatic triatomine were found: T. guasayana $(n=115), T$. sordida $(n=3)$ and $T$. platensis $(n=1)$. Their typical ecotopes were fallen trees and dense shrubs, where they were captured using Noireau traps. Triatoma guasayana was an active flyer seeking out potential hosts, with most flight activity occurring just after sunset. Both $T$. guasayana and $T$. sordida have been implicated as sylvatic vectors of $T$. cruzi in parts of the dry Chaco region (Wisnivesky-Colli et al. 1997; Vezzani et al. 2001). In Paraguayan localities, both species were frequently observed near and around households, especially the adults, which have a great capacity for flight (Yeo et al. 2005; Rolón et al. 2011). Because of these characteristics and their ability to colonize man made structures, they are candidate as secondary vectors. All our sylvatic T. guasayana and $T$. sordida captured in Paraguay were not infected with T. cruzi, apart from a single sylvatic Bolivian T. guasayana. However, infected T. guasayana and $T$. sordida have previously been reported in the Argentinean and Bolivian Chaco (Noireau et al. 2000; Bar et al. 2002; Lauricella et al. 2005; Ceballos et al. 2009) with average infection rates of 13.3 and $9 \cdot 1 \%$, respectively. In the Argentinean Chaco, sylvatic $T$. sordida have been reported with high infection rates $(38.5 \%$; Bar and WisniveskyColli, 2001; Bar et al. 2002).

Here we did not find $T$. infestans in the sylvatic ecotope. However, sylvatic 'dark morph' T. infestans have been reported in the Chaco region of Bolivia, in nests of Myiopsitta monachus (parrot), in bromeliads and hollows of live trees in several localities (Noireau et al. 1997a, b; Brenière et al. 2012; Waleckx et al. 2012), in the Argentinean Chaco (Ceballos et al. 2009, 2011) and Chile (Bacigalupo et al. 2006). Prevalence of $T$. cruzi infection is markedly lower in such 'dark morph' forms from the Chaco region with prevalence of between $2 \cdot 5$ and $12.5 \%$ (Noireau et al. 2000; Brenière et al. 2012; Waleckx et al. 2012) or zero (Ceballos et al. 2009, 2011) probably due that avian blood is the more often source of food. A few surveys have previously reported putative sylvatic populations of $T$. infestans in the Paraguayan Chaco, although they were also presumed attributable to dispersed peridomiciliary populations (Velázquez and González, 1959; Usinger et al. 1966; Yeo et al. 2005). More recently putative sylvatic colonies were discovered using a trained dog (Rolón et al. 2011), and these bugs were found $3 \mathrm{~km}$ from infested houses. It is significant that this species is capable of surviving in sylvatic ecotopes in at least in some regions of the Paraguayan Chaco. Further research is needed to establish the risk of reinvasion from such sylvatic populations of T. infestans.

Mammals. Eight species of mammals belonging to five different orders were captured in the study area. The overall prevalence of infection by $T$. cruzi was $12 \cdot 3 \%(17 / 138)$, although this percentage varied according to the genus. Armadillos were the most common species captured in both regions of Paraguay (Chaco and San Pedro Departments) and from different localities in Bolivia. In two recent 
surveys performed in the humid Argentinean Chaco, marsupials and rodents together with armadillos were the most frequently captured species (Alvarado-Otegui et al. 2012; Orozco et al. 2013). The scarce number of marsupials captured and none for rodents in our study is probably related to the environment, since most of our successful collections were from the dry zone of the Chaco. The highest rate of infection was observed in D. novemcinctus (28.5\%) followed by E. sexcinctus $(14 \cdot 8 \%)$ and Chaetophractus spp. $(4 \cdot 7 \%)$. In previous surveys in the same area, infection in armadillos ranged from 3 to $63 \%$, with the highest prevalence in the Dasypus (Yeo et al. 2005; Llewellyn et al. 2009). Dasypus novemcinctus and the other armadillo especies are commonly hunted by the inhabitants of rural communities for food or for handicraft products, and they may be kept alive for several days before being used. Thus, infected armadillos pose a risk for bringing sylvatic T. cruzi into the domestic habitat. The triatomine vectors involved in sylvatic transmission cycles in the Chaco region remain uncertain. Members of the genus Panstrongylus were reported associated with armadillo burrows in Brazil (Grisard et al. 2000), Venezuela (Llewellyn et al. 2009) and Argentina (Alvarado-Otegui et al. 2012). Our finding of one infected sylvatic $T$. guasayana in fallen trees in Bolivia could suggest some role in sylvatic transmission. The omnivorous behaviour of some mammal species also may contribute to their acquisition of infection (Rabinovich et al. 2001). The prevalence of $T$. cruzi infection in Chaetophractus spp. was lower than the other armadillos. Although this species construct their own burrows, they are nomadic and rarely use the same burrow twice, and thus unlikely to become infested with triatomines. Three other mammal species: T. tetradactyla (anteater), Dasyprocta spp. (agutí) and N. nasua (coati) from Bolivian localities were not infected with $T$. cruzi. Natural infection of $T$. tetradactyla by T. cruzi has been reported in Brazil (Miles et al. 1981; Bento et al. 1992; Fernandes et al. 1999) and Colombia (Ramírez et al. 2011). In addition, anteaters and coati are the known hosts of $T$. rangeli (Miles et al. 1983; Dereure et al. 2001).

Two D. albiventris of 14 captured $(14 \cdot 2 \%)$ from the Department of San Pedro were infected with T. cruzi, although isolates were not genotyped. These marsupials are usually found in humid areas, so the dry expanse of some Chaco zones may not be suitable for them. They are frequently observed in close proximity to human populations, and high T. cruzi infection rates have been found in Brazil (21.9 and 45.2\% prevalence; Grisard et al. 2000) and in the humid Chaco of Argentina (36 and 38\% prevalence; Alvarado-Otegui et al. 2012; Orozco et al. 2013). In San Pedro Department, $T$. cruzi has also been found in the terrestrial opossum Monodelphis domestica (Yeo et al. 2005). Further studies are needed to understand fully the role of marsupials in transmission of T. cruzi in Paraguay.

Host-vector of T. cruzi genotypes in the Paraguayan Chaco. Ours is the most comprehensive survey of T. cruzi genotypes in the Paraguayan Chaco region, providing new insight into the transmission dynamics and dispersion among domestic and sylvatic cycles.

TcII, TcIII, TcV and TcVI were circulating in the region, with the hybrids $\mathrm{TcV}$ and $\mathrm{TcVI}$ being most frequently found, supporting earlier observations (Yeo et al. 2005; Lauthier et al. 2012; Maffey et al. 2012; Pérez et al. 2013). TcV and TcVI were predominant and the most dispersed, and found solely infecting $T$. infestans in the domestic cycle, also in agreement with previous surveys (Chapman et al. 1984; Acosta et al. 2001; Yeo et al. 2005). $\mathrm{TcV}$ and $\mathrm{TcVI}$ were reported in domestic T. infestans in the Bolivian Chaco (Pérez et al. 2013), in domestic and peridomestic triatomines (T. infestans and $T$. sordida) and domestic dogs and cats in the Argentinean Chaco (Maffey et al. 2012; Enriquez et al. 2013). Thus, $\mathrm{TcV}$ and $\mathrm{TcVI}$ constitute the largest current threat to human health, and have been associated with severe chronic manifestations of Chagas disease in the southern Cone countries (Corrales et al. 2009; Cura et al. 2012; Vicco et al. 2012; Lucero et al. 2016). TcV and TcVI are infrequently reported in sylvatic cycles: $\mathrm{TcV}$ has been observed in one sylvatic D. novemcinctus and one E. sexcinctus in Paraguay (Yeo et al. 2005), in a rodent (Octodontomys spp.), three opossums, two ferrets and one skunk in Argentina (de Luca D'oro et al. 1993; Montamat et al. 1992), and in two sylvatic triatomines (Triatoma spp.) from the Bolivian Chaco (M. Llewellyn, unpublished data). There is one record of TcVI in a D. marsupialis in the Northeast La Paz (the Jungas and Alto Beni regions) in Bolivia (Valette et al. 1988). It has been suggested that the domestic predominance of $\mathrm{TcV}$ and TcVI may be due to their recent anthropogenic origin and rapid clonal dissemination with $T$. infestans and human migration (Lewis et al. 2011). The occurrence of sylvatic $\mathrm{TcV}$ and $\mathrm{TcVI}$ in other regions, such as the Atlantic forest, remains to be fully explored.

TcII was found only in domestic T. infestans, in agreement with previous surveys in the Paraguayan Chaco, where it is also associated within human infections (Acosta et al. 2001; Yeo et al. 2005), although in lower frequency than the $\mathrm{TcV}$ and TcVI hybrids. TcII has been detected in single triatomines carrying mixed infection with TcVI (Yeo et al. 2007), and the presence of TcII may have been underestimated as discriminatory markers have not been applied. Like $\mathrm{TcV}$ and TcVI, TcII rarely been reported in sylvatic cycles, although this may reflect limited research. Recently, TcII 
was reported infecting one sylvatic $T$. infestans in the Bolivian Chaco (Waleckx et al. 2012). Likewise, this DTU has been reported from one monkey (Acosta et al. 2016) and one E. sexcinctus, in Paraguay (Yeo et al. 2005) and from sylvatic mammals in Brazil (Fernandes et al. 1999; Bhattacharyya et al. 2015; Lisboa et al. 2015). Sylvatic TcII reservoirs are of particular interest as it is considered to be ancient (Westenberger et al. 2005; de Freitas et al. 2006).

A striking predominance of TcIII was apparent in sylvatic isolates. Twenty-nine sylvatic armadillos from Paraguay (both regions) and Bolivia, one sylvatic T. guasayana (from Bolivia) and two domestic $T$. infestans (from Paraguay) harboured TcIII. TcIII is frequently and widely found in sylvatic habitats with armadillos, particularly the genus Dasypus (Yeo et al. 2005; Llewellyn et al. 2009; Morocoima et al. 2012). Armadillos infected with TcIII were also reported in Colombia (Saravia et al. 1987), Venezuela (Llewellyn et al. 2009; Morocoima et al. 2012), Bolivia (Llewellyn et al. 2009), Brazil (Lisboa et al. 2009; Marcili et al. 2009b) and Argentina (Alvarado-Otegui et al. 2012; Orozco et al. 2013). In San Pedro (Paraguay), armadillos and one specimen of $M$. domestica (opossum) were infected previously with TcIII (Yeo et al. 2005). One sylvatic T. guasayana from the Bolivian Chaco carried TcIII, presumably acquired by feeding on an armadillo; this is the first report of TcIII in T. guasayana in Bolivia. Triatoma guasayana is frequently found near houses, attracted by light and $\mathrm{CO}_{2}$, may therefore introduce TcIII into the domestic cycle. This DTU has also been isolated from terrestrial sylvatic triatomines collected, such as P. geniculatus, T. rubrovaria, T. brasiliensis and T. vitticeps in Brazil (Póvoa et al. 1984; Martins et al. 2008; Santos-Mallet et al. 2008; Lisboa et al. 2009) and from Panstrongylus spp. associated with a burrow of $D$. novemcinctus in Venezuela (Llewellyn et al. 2009).

Two domestic T. infestans from the Chaco region of Paraguay harboured TcIII. Previously in the same region TcIII isolates were obtained from domestic dogs (Chapman et al. 1984) and from sylvatic armadillos (Yeo et al. 2005), suggesting leaky separation between domestic and sylvatic cycles. Dogs are commonly used for hunting of armadillos in the Chaco region, and dogs may thus introduce TcIII into the domestic transmission cycles, but TcIII has so far not been isolated from human cases of Chagas disease in the Chaco region. In contrast, in the eastern region of Paraguay (Cordillera and Paraguarí Departments), using amplification products of the 24S $\alpha$ rRNA, mini-exon and hybridization, TcIII was reported in human cases and domestic T. infestans (del Puerto et al. 2010) as well as from domestic and peridomestic T. sordida from Concepción Department (Sánchez et al.
2012); this interesting and surprising finding merits follow-up analyses.

Notably, TcI was absent from this survey. TcI has predominantly been found associated with arboreal marsupials, especially the Didelphis opossum throughout the Americas but also with rodents and other sylvatic mammals (Yeo et al. 2005; Messenger et al. 2015). Records of the presence and distribution of TcI in Paraguay are scarce. It has been identified in the direct analysis of feces of domestic T. infestans from the Chaco and eastern region (Cura et al. 2010), in samples from domestic $T$. sordida in Concepción Department (Sánchez et al. 2012), and in one human case from the Chaco region in a mixed infection with TcII (Risso et al. 2011). Unfortunately, isolates were not obtained from the two infected opossums from San Pedro Department. TcIV was not found among our many Chaco region isolates, but it has been reported by direct analysis of the intestinal contents of domestic and peridomestic $T$. sordida captured in Concepción Department (eastern region) (Sánchez et al. 2012), although additional analyses are required to confirm this observation.

Biological clones analysed in this study produced similar profiles to the original isolates with the combination of PCR techniques used in this study. The cloning technique on solid media has proven to be useful for discriminating mixed infections in $T$. cruzi reservoirs (Yeo et al. 2007), especially when a variety of DTUs are circulating sympatrically in the same area.

In summary, the distribution and the high prevalence of TcII, TcV and TcVI in domestic transmission cycles shows the remarkable diversity of $T$. cruzi in the Chaco region of Paraguay. In eight localities more than one T. cruzi DTU was present in the domestic transmission cycle showing the great capacity of $T$. infestans in indigenous communities to harbour a variety of $T$. cruzi populations. Furthermore, there is increasing evidence of interaction between domestic and sylvatic transmission cycles. Especially, TcIII in the Jope locality was found in both transmission cycles, suggesting introduction of TcIII into the domestic cycle. TcIII is known to be highly virulent in mice (Morocoima et al. 2012) and may therefore prove to be an agent of severe human Chagas disease. The abundance and aggressive nature of $T$. guasayana also carries a risk, if it should adapt to colonization of human dwellings.

The data generated here provide a regional baseline for future research and an indication of potential risks for human health. High-resolution analyses, including comparative genomics, will give further insight into $T$. cruzi transmission dynamics, interactions between sylvatic and transmission and molecular genetics, to inform the much needed improved control of Chagas disease in the Gran Chaco region. 


\section{ACKNOWLEDGEMENTS}

Special thanks to those who gave assistance in the fieldwork in Paraguay, Elvio Benitez, Pedro Recalde, Victoria Bogado (+), Mercedes Bogado, César Zelaya, Cecilio Lezcano and to Carlos Chura from Bolivia, for his help in collecting samples from Bolivia. Thanks to Dr Antonieta Rojas de Arias, Dr Celeste Vega and Dr Mirian Rolón from the Centro para el Desarrollo de la Investigación Científica (CEDIC)/Díaz Gill Medicina Laboratorial/Fundación Moisés Bertoni, Asunción, Paraguay for the T. cruzi isolates used in this study.

\section{FINANCIAL SUPPORT}

This survey was supported by Wellcome Trust funding, grant number 066806 .

\section{REFERENCES}

Acevedo, R., Aguilera, M., Miers, R., Velázquez, G. and Canese, J. (2002). Prevalencia de la enfermedad de Chagas en una población del Chaco Paraguayo. Revista Paraguaya de Microbiologia 22, 26-27.

Acosta, N., Samudio, M., López, E., Vargas, F., Yaksic, N., Brenière, S. F. and Rojas de Arias, A. (2001). Isoenzyme profiles of Trypanosoma cruzi stocks from different areas of Paraguay. Memorias do Instituto Oswaldo Cruz 96, 527-533.

Acosta, N., Miret, J., López, E. and Schinini, A. (2016). First report of Sapajus cay naturally infected by Trypanosoma cruzi in San Pedro Department, Paraguay. Revista Brasileira de Parasitologia Veterinária 25, 327-332.

Almeida, C. E., Vinhaes, M. C., de Almeida, J. R., Silveira, A. C. and Costa, J. (2000). Monitoring the domiciliary and peridomiciliary invasion process of Triatoma rubrovaria in the State of Rio Grande do Sul, Brazil. Memorias do Instituto Oswaldo Cruz 95, 761-768.

Alvarado-Otegui, J. A., Ceballos, L. A., Orozco, M. M., Enriquez, G. F., Cardinal, M. V., Cura, C., Schijman, A. G., Kitron, U. and Gürtler, R.E. (2012). The sylvatic transmission cycle of Trypanosoma cruzi in a rural area in the humid Chaco of Argentina. Acta Tropica 124, 79-86.

Bacigalupo, A., Segura, J. A., García, A., Hidalgo, J., Galuppo, S. and Cattan, P.E. (2006). First finding of Chagas disease vectors associated with wild bushes in the Metropolitan Region of Chile. Revista médica de Chile 134, 1230-1236.

Bar, M. E. and Wisnivesky-Colli, C. (2001). Triatoma sordida Stal 1859 (Hemiptera, Reduviidae: Triatominae) in Palms of Northeastern Argentina. Memorias do Instituto Oswaldo Cruz 96, 895-899.

Bar, M. E., Pieri Damborsky, M., Oscherov, E. B., Milano, A., Francisco, M., Avalos, G. and Wisnivesky-Colli, C. (2002). Triatomines involved in domestic and wild Trypanosoma cruzi transmission in Concepción, Corrientes, Argentina. Memorias do Instituto Oswaldo Cruz 97, 43-46.

Barnabé, C., Mobarec, H. I., Jurado, M. R., Cortez, J. A. and Brenière, S. F. (2016). Reconsideration of the seven discrete typing units within the species Trypanosoma cruzi, a new proposal of three reliable mitochondrial clades. Infection, Genetics and Evolution 39, 176-186. Bento, D. N., Farias, L. M., Godoy, M. F. and Araújo, J. F. (1992). The epidemiology of Chagas' disease in a rural area of the city of Teresina, Piauí, Brazil. Revista da Sociedade Brasileira de Medicina Tropical 25, 51-58.

Bhattacharyya, T., Mills, E. A., Jansen, A. M. and Miles, M. A. (2015). Prospects for T. cruzi lineage-specific serological surveillance of wild mammals. Acta Tropica 151, 182-186.

Brenière, S.F., Morochi, W., Bosseno, M.F., Ordoñez, J., Gutierrez, T., Vargas, F., Yaksic, N. and Noireau, F. (1998) Trypanosoma cruzi genotypes associated with domestic Triatoma sordida in Bolivia. Acta Tropica 71, 269-283.

Brenière, S. F., Aliaga, C., Waleckx, E., Buitrago, R., Salas, R., Barnabé, C., Tibayrenc, M. and Noireau, F. (2012). Genetic characterization of Trypanosoma cruzi DTUs in wild Triatoma infestans from Bolivia: predominance of TcI. PLoS Neglected Tropical Diseases 6, e1650.

Brenière, S. F., Waleckx, E. and Barnabé, C. (2016). Over six thousand Trypanosoma cruzi strains classified into discrete typing units (DTUs): attempt at an inventory. PLoS Neglected Tropical Diseases 10, e0004792.
Brisse, S., Barnabé, C. and Tibayrenc, M. (2000). Identification of six Trypanosoma cruzi phylogenetic lineages by random amplified polymorphic DNA and multilocus enzyme electrophoresis. International fournal for Parasitology 30, 35-44.

Canese, J. and Brice, E. (1977). Diagnóstico de la enfermedad de Chagas en aborígenes del Chaco paraguayo. Revista Paraguaya de Microbiologia 12, 9-10.

Ceballos, L. A., Piccinali, R.V., Berkunsky, I., Kitron, U. and Gürtler, R. E. (2009). First finding of melanic sylvatic Triatoma infestans (Hemiptera: Reduviidae) colonies in the Argentine Chaco. Fournal of Medical Entomology 46, 1195-1202.

Ceballos, L. A., Piccinali, R. V., Marcet, P. L., Vazquez-Prokopec, G. M., Cardinal, M. V., Schachter-Broide, J., Dujardin, J.P., Dotson, E. M., Kitron, U. and Gürtler, R.E. (2011). Hidden sylvatic foci of the main vector of Chagas disease Triatoma infestans: threats to the vector elimination campaign? PLoS Neglected Tropical Diseases 5, e1365.

Cécere, M. C., Vázquez-Prokopec, G. M., Ceballos, L.A., Boragno, S., Zárate, J. E., Kitron, U. and Gürtler, R. E. (2013). Improved chemical control of Chagas disease vectors in the dry Chaco region. Fournal of Medical Entomology 50, 394-403.

Chapman, M. D., Baggaley, R. C., Godfrey-Fausset, P. F., Malpas, T. J., White, G., Canese, J. and Miles, M. A. (1984). Trypanosoma cruzi from the Paraguayan Chaco: isoenzyme profiles of strains isolated at Makthlawaiya. The Fournal of Protozoology 31, 482-486.

Corrales, R. M., Mora, M. C., Negrette, O.S., Diosque, P., Lacunza, D., Virreira, M., Brenière, S. F. and Basombrio, M. A. (2009). Congenital Chagas disease involves Trypanosoma cruzi sublineage IId in the northwestern province of Salta, Argentina. Infection, Genetics and Evolution 9, 278-282.

Cura, C. I., Mejía-Jaramillo, A. M., Duffy, T., Burgos, J. M., Rodriguero, M., Cardinal, M. V., Kjos, S., Gurgel-Gonçalves, R., Blanchet, D., De Pablos, L. M., Tomasini, N., da Silva, A., Russomando, G., Cuba, C. A., Aznar, C., Abate, T., Levin, M. J., Osuna, A., Gürtler, R. E., Diosque, P., Solari, A., Triana-Chávez, O. and Schijman, A. G. (2010). Trypanosoma cruzi I genotypes in different geographical regions and transmission cycles based on a microsatellite motif of the intergenic spacer of spliced-leader genes. International Fournal for Parasitology 40, 1599-1607.

Cura, C. I., Lucero, R. H., Bisio, M., Oshiro, E., Formichelli, L. B., Burgos, J. M., Lejona, S., Brusés, B. L., Hernández, D. O., Severini, G. V., Velázquez, E., Duffy, T., Anchart, E., Lattes, R., Altcheh, J., Freilij, H., Diez, M., Nagel, C., Vigliano, C., Favaloro, L., Favaloro, R. R., Merino, D. E., Sosa-Estani, S. and Schijman, A.G. (2012). Trypanosoma cruzi discrete typing units in Chagas disease patients from endemic and non-endemic regions of Argentina. Parasitology 139, 516-521.

Damborsky, M. P., Bar, M. E. and Oscherov, E. B. (2001). Detection of triatomines (Hemiptera: Reduviidae) in domiciliary and extra-domiciliary ecotopes. Corrientes, Argentina. Cadernos de Saúde Pública 17, 843-849. de Freitas, J.M., Augusto-Pinto, L., Pimenta, J.R., BastosRodrigues, L., Gonçalves, V.F., Teixeira, S. M., Chiari, E., Junqueira, A. C., Fernandes, O., Macedo, A. M., Machado, C. R. and Pena, S. D. (2006). Ancestral genomes, sex, and the population structure of Trypanosoma cruzi. PLoS Pathogens 2, e24.

del Puerto, F., Sánchez, Z., Nara, E., Meza, G., Paredes, B., Ferreira, E. and Russomando, G. (2010). Trypanosoma cruzi lineages detected in congenitally infected infants and Triatoma infestans from the same disease-endemic region under entomologic surveillance in Paraguay. The American Fournal of Tropical Medicine and Hygiene 82, 386-390.

de Luca D'oro, G. M., Gardenal, C. N., Perret, B., Crisci, J. V. and Montamat, E. E. (1993). Genetic structure of Trypanosoma cruzi populations from Argentina estimated from enzyme polymorphism. Parasitology 107, 405-410.

Dereure, J., Barnabé, C., Vie, J. C., Madelenat, F. and Raccurt, C. (2001). Trypanosomatidae from wild mammals in the neotropical rainforest of French Guiana. Annals of Tropical Medicine and Parasitology 95, $157-166$.

Diotaiuti, L., Pereira, A.S., Loiola, C. F., Fernandes, A. J., Schofield, J. C., Dujardin, J.P., Dias, J. C. and Chiari, E. (1995). Inter-relation of sylvatic and domestic transmission of Trypanosoma cruzi in areas with and without domestic vectorial transmission in Minas Gerais, Brazil. Memorias do Instituto Oswaldo Cruz 90, 443-448.

Enriquez, G.F., Cardinal, M.V., Orozco, M. M., Lanati, L., Schijman, A. G. and Gürtler, R.E. (2013). Discrete typing units of Trypanosoma cruzi identified in rural dogs and cats in the humid Argentinean Chaco. Parasitology 140, 303-308. 
Feliciangeli, M.D., Campbell-Lendrum, D., Martinez, C., Gonzalez, D., Coleman, P. and Davies, C. (2003). Chagas disease control in Venezuela: lessons for the Andean region and beyond. Trends in Parasitology 19, 44-49.

Fernandes, O., Mangia, R. H., Lisboa, C. V., Pinho, A. P., Morel, C. M., Zingales, B., Campbell, D. A. and Jansen, A. M. (1999). The complexity of the sylvatic cycle of Trypanosoma cruzi in Rio de Janeiro state (Brazil) revealed by the non-transcribed spacer of the mini-exon gene. Parasitology 118, 161-166.

Gaspe, M. S., Provecho, Y.M., Piccinali, R. V. and Gürtler, R. E. (2015). Where do these bugs come from? Phenotypic structure of Triatoma infestans populations after control interventions in the Argentine Chaco. Memorias do Instituto Oswaldo Cruz 110, 310-318.

Gracey, M. and King, M. (2009). Indigenous health part 1: determinants and disease patterns. The Lancet 374, 65-75.

Grisard, E. C., Carvalho-Pinto, C. J., Scholz, A. F., Toma, H. K., Schlemper, B. R. and Steindel, M. (2000). Trypanosoma cruzi infection in Didelphis marsupialis in Santa Catarina and Arvoredo Islands, southern Brazil. Memorias do Instituto Oswaldo Cruz 95, 795-800.

Gurevitz, J. M., Ceballos, L. A., Gaspe, M. S., Alvarado-Otegui, J. A., Enríquez, G. F., Kitron, U. and Gürtler, R. E. (2011). Factors affecting infestation by Triatoma infestans in a rural area of the humid Chaco in Argentina: a multi-model inference approach. PLoS Neglected Tropical Diseases 5, e1349.

Gurevitz, J.M., Gaspe, M.S., Enríquez, G. F., Vassena, C. V., Alvarado-Otegui, J. A., Provecho, Y. M., Cueto, G. A., Picollo, M. I., Kitron, U. and Gürtler, R. E. (2012). Unexpected failures to control Chagas disease vectors with pyrethroid spraying in northern Argentina. Fournal of Medical Entomology 49, 1379-1386.

Gürtler, R. E. (2009). Sustainability of vector control strategies in the Gran Chaco region: current challenges and possible approaches. Memorias do Instituto Oswaldo Cruz 104, 52-59.

Gürtler, R. E., Chuit, R., Cécere, M. C., Castañera, M. B., Cohen, J. E. and Segura, E. L. (1998). Household prevalence of seropositivity for Trypanosoma cruzi in three rural villages in northwest Argentina: environmental, demographic, and entomologic associations. The American fournal of Tropical Medicine and Hygiene 59, 741-749.

Gürtler, R. E., Kitron, U., Cécere, M. C., Segura, E. L. and Cohen, J. E. (2007). Sustainable vector control and management of Chagas disease in the Gran Chaco, Argentina. Proceedings of the National Academy of Sciences of the United States of America 104, 16194-16199.

Hotez, P. J. (2014a). Ten global "hotspots" for the neglected tropical diseases. PLoS Neglected Tropical Diseases 8, e2496.

Hotez, P. J. (2014b). Aboriginal populations and their neglected tropical diseases. PLoS Neglected Tropical Diseases 8, e2286.

Kawashita, S. Y., Sanson, G. F., Fernandes, O., Zingales, B. and Briones, M. R. (2001). Maximum-likelihood divergence date estimates based on rRNA gene sequences suggest two scenarios of Trypanosoma cruzi intraspecific evolution. Molecular Biology and Evolution 18 2250-2259.

Lardeux, F., Depickère, S., Duchon, S. and Chávez, T. (2010). Insecticide resistance of Triatoma infestans (Hemiptera, Reduviidae) vector of Chagas disease in Bolivia. Tropical Medicine and International Health 15, 1037-1048.

Lauricella, M. A., Stariolo, R. L., Riarte, A. R., Segura, E. L. and Gürtler, R.E. (2005). Distribution and pathogenicity of Trypanosoma cruzi isolated from peridomestic populations of Triatoma infestans and Triatoma guasayana from rural Western Argentina. Memorias do Instituto Oswaldo Cruz 100, 123-129.

Lauthier, J. J., Tomasini, N., Barnabé, C., Rumi, M. M., D'Amato, A. M., Ragone, P. G., Yeo, M., Lewis, M.D., Llewellyn, M.S., Basombrío, M. A., Miles, M. A., Tibayrenc, M. and Diosque, P. (2012). Candidate targets for multilocus sequence typing of Trypanosoma cruzi: validation using parasite stocks from the Chaco Region and a set of reference strains. Infection, Genetics and Evolution 12, 350-358.

Lent, H. and Wygodzinsky, P. (1979). Revision of the Triatominae (Hemiptera, Reduviidae), and their significance as vectors of Chagas disease. Bulletin of the American Museum of Natural History 163, 123-520. Lewis, M. D., Ma, J., Yeo, M., Carrasco, H. J., Llewellyn, M. S. and Miles, M. A. (2009). Genotyping of Trypanosoma cruzi: systematic selection of assays allowing rapid and accurate discrimination of all known lineages. The American Fournal of Tropical Medicine and Hygiene 81, 1041-1049. Lewis, M. D., Llewellyn, M. S., Yeo, M., Acosta, N., Gaunt, M. W. and Miles, M. A. (2011). Recent, independent and anthropogenic origins of Trypanosoma cruzi hybrids. PLoS Neglected Tropical Diseases 5, e1363. Lisboa, C. V., Xavier, S. C., Herrera, H. M. and Jansen, A. M. (2009). The ecology of the Trypanosoma cruzi transmission cycle: dispersion of zymodeme $3(\mathrm{Z} 3)$ in wild hosts from Brazilian biomes. Veterinary Parasitology 165, 19-24.

Lisboa, C. V., Monteiro, R. V., Martins, A. F., Xavier, S. C., Lima, V. D. and Jansen, A. M. (2015). Infection with Trypanosoma cruzi TcII and $\mathrm{TcI}$ in free-ranging population of lion tamarins (Leontopithecus spp): an 11year follow-up. Memorias do Instituto Oswaldo Cruz 110, 394-402.

Llewellyn, M. S., Lewis, M. D., Acosta, N., Yeo, M., Carrasco, H. J., Segovia, M., Vargas, J., Torrico, F., Miles, M. A. and Gaunt, M. W. (2009). Trypanosoma cruzi IIc: phylogenetic and phylogeographic insights from sequence and microsatellite analysis and potential impact on emergent Chagas disease. PLoS Neglected Tropical Diseases 3, e510.

Lucero, R. H., Brusés, B. L., Cura, C. I., Formichelli, L. B., Juiz, N., Fernández, G. J., Bisio, M., Deluca, G. D., Besuschio, S., Hernández, D. O. and Schijman, A. G. (2016). Chagas' disease in aboriginal and Creole communities from the Gran Chaco Region of Argentina: seroprevalence and molecular parasitological characterization. Infection, Genetics and Evolution 41, 84-92.

Macchiaverna, N. P., Gaspe, M. S., Enriquez, G. F., Tomassone, L., Gürtler, R. E. and Cardinal, M. V. (2015). Trypanosoma cruzi infection in Triatoma sordida before and after community-wide residual insecticide spraying in the Argentinean Chaco. Acta Tropica 143, 97-102.

Maffey, L., Cardinal, M. V., Ordóñez-Krasnowski, P. C., Lanati, L. A., Lauricella, M. A., Schijman, A. G. and Gürtler, R.E. (2012). Direct molecular identification of Trypanosoma cruzi discrete typing units in domestic and peridomestic Triatoma infestans and Triatoma sordida from the Argentine Chaco. Parasitology 139, 1570-1579.

Marcili, A., Lima, L., Cavazzana, M., Junqueira, A. C., Veludo, H. H., Maia Da Silva, F., Campaner, M., Paiva, F., Nunes, V. L. and Teixeira, M. M. (2009a). A new genotype of Trypanosoma cruzi associated with bats evidenced by phylogenetic analyses using SSU rDNA, cytochrome $\mathrm{b}$ and Histone $\mathrm{H} 2 \mathrm{~B}$ genes and genotyping based on ITS1 rDNA. Parasitology 136, 641-655.

Marcili, A., Lima, L., Valente, V.C., Valente, S. A., Batista, J.S., Junqueira, A. C., Souza, A. I., da Rosa, J. A., Campaner, M., Lewis, M. D., Llewellyn, M. S., Miles, M. A. and Teixeira, M. M. (2009b). Comparative phylogeography of Trypanosoma cruzi TCIIc: new hosts, association with terrestrial ecotopes, and spatial clustering. Infection, Genetics and Evolution 9, 1265-1274.

Martins, L.P., Marcili, A., Castanho, R.E., Therezo, A. L., de Oliveira, J. C., Suzuki, R. B., Teixeira, M. M., da Rosa, J. A. and Sperança, M. A. (2008). Rural Triatoma rubrovaria from southern Brazil harbors Trypanosoma cruzi of lineage IIc. The American fournal of Tropical Medicine and Hygiene 79, 427-434.

Messenger, L. A., Miles, M. A. and Bern, C. (2015). Between a bug and a hard place: Trypanosoma cruzi genetic diversity and the clinical outcomes of Chagas disease. Expert Review of Anti-Infective Therapy 13, 995-1029

Miles, M., Feliciangeli, D. and Rojas de Arias, A. (2003). American tripanosomiasis (Chagas disease) and the role of molecular epidemiology in guiding control strategies. British Medical Fournal 326, 1444-1448.

Miles, M. A. (1993). Culturing and biological cloning of Trypanosoma cruzi. In Protocols in Molecular Parasitology, vol. 21 (ed. Hyde, J. E.), pp. 15-28. Springer, London.

Miles, M. A., Póvoa, M. M., De Souza, A. A., Lainson, R., Shaw, J. J. and Ketteridge, D. S. (1981). Chagas's disease in the Amazon Basin: the distribution of Trypanosoma cruzi zymodemes 1 and 3 in Pará State, north Brazil. Transactions of the Royal Society of Tropical Medicine and Hygiene 75, 667-674.

Miles, M. A., Arias, J. R., Valente, S. A., Naiff, R. D., de Souza, A. A., Póvoa, M. M., Lima, J. A. and Cedillos, R. A. (1983). Vertebrate hosts and vectors of Trypanosoma rangeli in the Amazon Basin of Brazil. The American Fournal of Tropical Medicine and Hygiene 32, 1251-1259.

Miles, M. A., Llewellyn, M.S., Lewis, M. D., Yeo, M., Baleela, R., Fitzpatrick, S., Gaunt, M. W. and Mauricio, I. L. (2009). The molecular epidemiology and phylogeography of Trypanosoma cruzi and parallel research on Leishmania: looking back and to the future. Parasitology 136, 1509-1528.

Montamat, E. E., De Luca d'Oro, G., Perret, B. and Rivas, C. (1992) Characterization of Trypanosoma cruzi from Argentina by electrophoretic zymograms. Acta Tropica 51, 173

Moretti, E., Castro, I., Franceschi, C. and Basso, B. (2010). Chagas disease: serological and electrocardiographic studies in Wichi and Creole communities of Misión Nueva Pompeva, Chaco, Argentina. Memorias do Instituto Oswaldo Cruz 105, 621-627.

Morocoima, A., Carrasco, H. J., Boadas, J., Chique, J. D., Herrera, L. and Urdaneta-Morales, S. (2012). Trypanosoma cruzi III from armadillos (Dasypus novemcinctus novemcinctus) from Northeastern Venezuela and 
its biological behavior in murine model. Risk of emergency of Chagas' disease. Experimental Parasitology 132, 341-347.

Neris, N., Colmán, F., Ovelar, E., Sukigara, N. and Ishii, N. (2002). Guía de mamíferos medianos y grandes del Paraguay. Distribución, tendencia poblacional y utilización. Secretaría del Ambiente/Agencia de Cooperación Internacional para el Desarrollo, Asunción.

Noireau, F., Flores, R., Gutierrez, T. and Dujardin, J.P. (1997a) Detection of sylvatic dark morphs of Triatoma infestans in the Bolivian Chaco. Memorias do Instituto Oswaldo Cruz 92, 583-584.

Noireau, F., Brenière, F., Ordoñez, J., Cardozo, L., Morochi, W., Gutierrez, T., Bosseno, M. F., Garcia, S., Vargas, F., Yaksic, N., Dujardin, J.P., Peredo, C. and Wisnivesky-Colli, C. (1997b). Low probability of transmission of Trypanosoma cruzi to humans by domiciliary Triatoma sordida in Bolivia. Transactions of the Royal Society of Tropical Medicine and Hygiene 91, 653-656.

Noireau, F., Gutierrez, T., Zegarra, M., Flores, R., Brenière, F., Cardozo, L. and Dujardin, J. P. (1998). Cryptic speciation in Triatoma sordida (Hemiptera:Reduviidae) from the Bolivian Chaco. Tropical Medicine and International Health 3, 364-372.

Noireau, F., Flores, R., Gutierrez, T., Abad-Franch, F., Flores, E. and Vargas, F. (2000). Natural ecotopes of Triatoma infestans dark morph and other sylvatic triatomines in the Bolivian Chaco. Transactions of the Royal Society of Tropical Medicine and Hygiene 94, 23-27. Orozco, M. M., Enriquez, G. F., Alvarado-Otegui, J. A., Cardinal, M. V., Schijman, A. G., Kitron, U. and Gürtler, R. E. (2013). New sylvatic hosts of Trypanosoma cruzi and their reservoir competence in the humid Chaco of Argentina: a longitudinal study. The American Fournal of Tropical Medicine and Hygiene 88, 872-882.

Pérez, E., Monje, M., Chang, B., Buitrago, R., Parrado, R. Barnabé, C., Noireau, F. and Brenière, S. F. (2013). Predominance of hybrid discrete typing units of Trypanosoma cruzi in domestic Triatoma infestans from the Bolivian Gran Chaco region. Infection, Genetics and Evolution 13, 116-123.

Póvoa, M. M., de Souza, A. A., Naiff, R. D., Arias, J. R., Naiff, M. F., Biancardi, C. B. and Miles, M. A. (1984). Chagas' disease in the Amazon basin IV. Host records of Trypanosoma cruzi zymodemes in the states of Amazonas and Rondônia, Brazil. Annals of Tropical Medicine and Parasitology 78, 479-487.

Provecho, Y.M., Gaspe, M.S., del Pilar Fernández, M., Enriquez, G.F., Weinberg, D. and Gürtler, R.E. (2014). The periurban interface and house infestation with Triatoma infestans in the Argentine Chaco: an underreported process? Memorias do Instituto Oswaldo Cruz 109, 923-934.

Quisberth, S., Waleckx, E., Monje, M., Chang, B., Noireau, F. and Brenière, S. F. (2011). "Andean" and "non-Andean" ITS-2 and mtCytB haplotypes of Triatoma infestans are observed in the Gran Chaco (Bolivia): population genetics and the origin of reinfestation. Infection, Genetics and Evolution 11, 1006-1014.

Rabinovich, J. E., Schweigmann, N., Yohai, V. and WisniveskyColli, C. (2001). Probability of Trypanosoma cruzi transmission by Triatoma infestans (Hemiptera: Reduviidae) to the opossum Didelphis albiventris (Marsupiala: Didelphidae). The American Fournal of Tropical Medicine and Hygiene 65, 125-130.

Ramírez, J. D., Duque, M. C. and Guhl, F. (2011). Phylogenetic reconstruction based on Cytochrome b (Cytb) gene sequences reveals distinct genotypes within Colombian Trypanosoma cruzi I populations. Acta Tropica 119, 61-65.

Risso, M. G., Sartor, P. A., Burgos, J. M., Briceño, L., Rodríguez, E. M., Guhl, F., Chavez, O.T., Espinoza, B. Monteón, V.M., Russomando, G., Schijman, A. G., Bottasso, O. A. and Leguizamón, M.S. (2011). Immunological identification of Trypanosoma cruzi lineages in human infection along the endemic area. The American Fournal of Tropical Medicine and Hygiene 84, 78-84. Rojas de Arias, A. (2003). Control y Vigilancia de Chagas con la participación comunitaria de etnias indígenas: Una perspectiva de la situación. XIIa. Reunión Intergubernamental INCOSUR/Chagas, Santiago, Chile, Marzo de 2003 (PAHO document), pp. 121-124.

Rojas de Arias, A., Velázquez de Saldívar, G., Merlo, R., Monzón de Calabró, M., Gamarra de Galaher, P. and Keller, F. (1990). Seroepidemiología de la enfermedad de Chagas en el Paraguay: un estudio de dos localidades del Chaco Paraguayo. Memorias del Instituto de Investigaciones en Ciencias de la Salud 15, 253-264.

Rojas de Arias, A., Arévalo de Guillén, I., Inchaustti, A., Samudio, M. and Schmeda-Hischmann, G. (1993). Prevalence of Chagas disease in Ayoreo communities of the Paraguayan Chaco. Tropical Medicine and Parasitology 44, 285-288.

Rojas de Arias, A., Rolón, M., Vega, M. C., Gómez, A., Román, F., Sánchez, H., Acosta, C., Villalba, C., Cécere, C., Marcet, P. and
Dotson, E. (2011). Molecular epidemiology and ecosystem approach of the reinfestation process by Triatoma infestans in rural communities of the Paraguayan Chaco. XV Congreso Colombiano de Parasitología y Medicina Tropical. Biomédica 31, 314-315.

Rolón, M., Vega, M. C., Román, F., Gómez, A. and Rojas de Arias, A. (2011). First report of colonies of sylvatic Triatoma infestans (Hemiptera: Reduviidae) in the Paraguayan Chaco, using a trained dog. PLoS Neglected Tropical Diseases 5, e1026.

Samuels, A. M., Clark, E. H., Galdos-Cardenas, G., Wiegand, R.E., Ferrufino, L., Menacho, S., Gil, J., Spicer, J., Budde, J., Levy, M. Z., Bozo, R. W., Gilman, R. H. and Bern, C. (2013). Epidemiology of and impact of insecticide spraying on Chagas disease in communities in the Bolivian Chaco. PLoS Neglected Tropical Diseases 7, e2358.

Sánchez, Z., Russomando, G. and Guillén, R. (2012). Enfermedad de Chagas: estudio de un vector secundario. Editorial Académica Española. LAP LAMBERT Academic Publishing GmbH \& Co. KG., Saabrucken, Alemania, pp. 1-100. ISBN-13: 978-3-659-03664-4.

Santos-Mallet, J.R., Silva, C.S., Gomes, S. A., Oliveira, D. L., Santos, C. L., Sousa, D. M., Pinheiro, N. L., Junqueira, A. C. and Gonçalves, T.C. (2008). Molecular characterization of Trypanosoma cruzi sylvatic isolates from Rio de Janeiro, Brazil. Parasitology Research 103, 1041-1045.

Saravia, N. G., Holguín, A. F., Cibulskis, R. E. and D'Alessandro, A. (1987). Divergent isoenzyme profiles of sylvatic and domiciliary Trypanosoma cruzi in the eastern plains, piedmont, and highlands of Colombia. The American fournal of Tropical Medicine and Hygiene 36, 59-69. Sikes, R. S. and Gannon, W. L. (2011). Guidelines of the American Society of Mammalogists for the use of wild mammals in research. Fournal of Mammalogy 92, 235-253.

Souto, R.P., Fernandes, O., Macedo, A. M., Campbell, D. A. and Zingales, B. (1996). DNA markers define two major phylogenetic lineages of Trypanosoma cruzi. Molecular and Biochemical Parasitology 83, 141-152.

Usinger, R. L., Wygodzinsky, P. and Ryckman, R. E. (1966). The biosystematics of Triatominae. Annual Review of Entomology 11, 309-330.

Valette, E., Brenière, S. F., Le Pont, F. and Desjeux, P. (1988) Zymodemes of Trypanosoma cruzi isolated from wild mammals in Bolivia. Memorias do Instituto Oswaldo Cruz 83, 139-140.

Vazquez-Prokopec, G. M., Ceballos, L. A., Marcet, P. L., Cécere, M. C., Cardinal, M. V., Kitron, U. and Gürtler, R. E. (2006). Seasonal variations in active dispersal of natural populations of Triatoma infestans in rural north-western Argentina. Medical and Veterinary Entomology 20, 273-279.

Velázquez, C. J. and González, G. (1959). Aspectos de la enfermedad de Chagas en el Paraguay. Revista Goiana de Medicina 5, 357-373.

Vezzani, D., Schweigmann, N. J., Pietrokovsky, S. M. and Wisnivesky-Colli, C. (2001). Characterization of Triatoma guasayana biotopes in a hardwood forest of Santiago del Estero, Argentina. Memorias do Instituto Oswaldo Cruz 96, 459-466.

Vicco, M. H., Bontempi, I., Ortiz, S., Solari, A., Bottasso, O. A. and Marcipar, I. (2012). Chronic Chagas disease with cardiodigestive involvement and the TcVI infective form of Trypanosoma cruzi. A case report. Parasitology International 61, 735-737.

Waleckx, E., Depickère, S., Salas, R., Aliaga, C., Monje, M., Calle, H., Buitrago, R., Noireau, F. and Brenière, S. F. (2012). New discoveries of sylvatic Triatoma infestans (Hemiptera: Reduviidae) throughout the Bolivian Chaco. The American Fournal of Tropical Medicine and Hygiene 86, 455-458.

Westenberger, S. J., Barnabé, C., Campbell, D. A. and Sturm, N. R. (2005). Two hybridization events define the population structure of Trypanosoma cruzi. Genetics 171, 527-543.

Wisnivesky-Colli, C., Schweigmann, N. J., Pietrokovsky, S. Bottazi, V. and Rabinovich, J.E. (1997). Spatial distribution of Triatoma guasayana (Hemiptera: Reduviidae) in hardwood forest biotopes in Santiago del Estero, Argentina. Fournal of Medical Entomology 34, 102-109.

World Health Organization (2015). Chagas disease in Latin America: an epidemiological update based on 2010 estimates. Weekly Epidemiological Record 90, 33-43.

Yeo, M., Acosta, N., Llewellyn, M., Sánchez, H., Adamson, S., Miles, G. A., López, E., González, N., Patterson, J. S., Gaunt, M. W., de Arias, A. R. and Miles, M. A. (2005). Origins of Chagas disease: Didelphis species are natural hosts of Trypanosoma cruzi I and armadillos hosts of Trypanosoma cruzi II, including hybrids. International fournal for Parasitology 35, 225-233.

Yeo, M., Lewis, M. D., Carrasco, H. J., Acosta, N., Llewellyn, M., da Silva Valente, S. A., de Costa Valente, V., de Arias, A.R. and Miles, M. A. (2007). Resolution of multiclonal infections of 
Trypanosoma cruzi from naturally infected triatomine bugs and from experimentally infected mice by direct plating on a sensitive solid medium. International fournal for Parasitology 37, 111-120.

Zelada, J., Sanabria, V., Canese, A. and Canese, J. (1998). Enfermedad de Chagas en comunidades indígenas del Chaco Paraguayo. Revista Paraguaya de Microbiologia 18, 13-17.
Zingales, B., Miles, M.A., Campbell, D. A., Tibayrenc, M., Macedo, A. M., Teixeira, M. M., Schijman, A. G., Llewellyn, M. S., Lages-Silva, E., Machado, C. R., Andrade, S. G. and Sturm, N. R. (2012). The revised Trypanosoma cruzi subspecific nomenclature: rationale, epidemiological relevance and research applications. Infection, Genetics and Evolution 12, 240-253.

APPENDIX A

Table A1. Localities surveyed in the Chaco (Paraguay and Bolivia) and San Pedro Departments

\begin{tabular}{|c|c|c|c|c|c|c|}
\hline Country & Department & Locality & Ethnic group & Latitude & Longitude & $\begin{array}{l}\text { Inhabitants } \\
\text { (approx.) }^{\mathrm{a}}\end{array}$ \\
\hline \multirow{22}{*}{ Paraguay } & Boquerón & Betania & Nivaclé & $22^{\circ} 36^{\prime} 1 \cdot 6^{\prime \prime} \mathrm{S}$ & $59^{\circ} 48^{\prime} 54 \cdot 05^{\prime \prime} \mathrm{W}$ & 363 \\
\hline & Boquerón & Jerico & Nivaclé & $22^{\circ} 35^{\prime} 52 \cdot 71^{\prime \prime} \mathrm{S}$ & $59^{\circ} 48^{\prime} 34 \cdot 24^{\prime \prime} \mathrm{W}$ & 153 \\
\hline & Boquerón & Cesarea & Nivaclé & $22^{\circ} 35^{\prime} 32 \cdot 59^{\prime \prime} \mathrm{S}$ & $59^{\circ} 49^{\prime} 11 \cdot 72^{\prime \prime} \mathrm{W}$ & 144 \\
\hline & Boquerón & Samaria & Nivaclé & $22^{\circ} 35^{\prime} 55 \cdot 58^{\prime \prime} \mathrm{S}$ & $59^{\circ} 49^{\prime} 54 \cdot 41^{\prime \prime} \mathrm{W}$ & 164 \\
\hline & Boquerón & Tiberia & Nivaclé & $22^{\circ} 36^{\prime} 41^{\prime \prime} \mathrm{S}$ & $59^{\circ} 50^{\prime} 44 \cdot 93^{\prime \prime} \mathrm{W}$ & 220 \\
\hline & Boquerón & Galilea & Nivaclé & $22^{\circ} 35^{\prime} 4 \cdot 44^{\prime \prime} \mathrm{S}$ & $59^{\circ} 56^{\prime} 46 \cdot 44^{\prime \prime} \mathrm{W}$ & 120 \\
\hline & Boquerón & Campo Nuevo & Nivaclé & $22^{\circ} 34^{\prime} 26^{\prime} 13^{\prime \prime} \mathrm{S}$ & $59^{\circ} 55^{\prime} 34 \cdot 76^{\prime \prime} \mathrm{W}$ & 187 \\
\hline & Boquerón & Campo Salado & Nivaclé & $22^{\circ} 34^{\prime} 54 \cdot 84^{\prime \prime} \mathrm{S}$ & $59^{\circ} 57^{\prime} 00 \cdot 96^{\prime \prime} \mathrm{W}$ & 93 \\
\hline & Boquerón & Campo Alegre & Lengua & $22^{\circ} 51^{\prime} 09^{\prime \prime} \mathrm{S}$ & $60^{\circ} 02^{\prime} 10^{\prime \prime} \mathrm{W}$ & 348 \\
\hline & Boquerón & Casuarina & Nivaclé & $22^{\circ} 54^{\prime} 21 \cdot 63^{\prime \prime} \mathrm{S}$ & $60^{\circ} 00^{\prime} 4 \cdot 45^{\prime \prime} \mathrm{W}$ & 274 \\
\hline & Boquerón & Jotoisha & Nivaclé & $22^{\circ} 26^{\prime} 48 \cdot 86^{\prime \prime} \mathrm{S}$ & $60^{\circ} 37^{\prime} 11 \cdot 63^{\prime \prime} \mathrm{W}$ & 282 \\
\hline & Boquerón & Campo Loro & Ayoreo & $22^{\circ} 4^{\prime} 48 \cdot 58^{\prime \prime} \mathrm{S}$ & $59^{\circ} 50^{\prime} 29 \cdot 19^{\prime \prime} \mathrm{W}$ & 651 \\
\hline & Presidente Hayes & 12 de Junio & Angaité & $22^{\circ} 56^{\prime} 10^{\prime \prime} \mathrm{S}$ & $59^{\circ} 53^{\prime} 45 \cdot 4^{\prime \prime} \mathrm{W}$ & 290 \\
\hline & Presidente Hayes & 20 de abril & Nivaclé & $22^{\circ} 57^{\prime} 57 \cdot 25^{\prime \prime} \mathrm{S}$ & $59^{\circ} 52^{\prime} 1 \cdot 1^{\prime \prime} \mathrm{W}$ & 84 \\
\hline & Presidente Hayes & Campo Largo & Nivaclé & $22^{\circ} 49^{\prime} 44^{\prime \prime} \mathrm{S}$ & $59^{\circ} 54^{\prime} 9 \cdot 3^{\prime \prime} \mathrm{W}$ & 506 \\
\hline & Presidente Hayes & 10 Leguas & Angaité & $22^{\circ} 52^{\prime} 8 \cdot 6^{\prime \prime} \mathrm{S}$ & $59^{\circ} 52^{\prime} 30 \cdot 3^{\prime \prime} \mathrm{W}$ & 278 \\
\hline & Presidente Hayes & Jope & Nivaclé & $22^{\circ} 35^{\prime} 55 \cdot 91^{\prime \prime} \mathrm{S}$ & $59^{\circ} 47^{\prime} 13 \cdot 03^{\prime \prime} \mathrm{W}$ & 351 \\
\hline & Presidente Hayes & Fischat & Nivaclé & $23^{\circ} 47^{\prime} 27 \cdot 64^{\prime \prime} \mathrm{S}$ & $60^{\circ} 47^{\prime} 0 \cdot 09^{\prime \prime} \mathrm{W}$ & 731 \\
\hline & Presidente Hayes & Estancia Salazar & Sanapana & $23^{\circ} 4^{\prime} 20 \cdot 86^{\prime \prime} \mathrm{S}$ & $59^{\circ} 14^{\prime} 12 \cdot 09^{\prime \prime} \mathrm{W}$ & 472 \\
\hline & San Pedro & San Pedro & & $24^{\circ} 11^{\prime} 37 \cdot 59^{\prime \prime} \mathrm{S}$ & $56^{\circ} 34^{\prime} 45 \cdot 12^{\prime \prime} \mathrm{W}$ & \\
\hline & San Pedro & San Alfredo & & $24^{\circ} 34^{\prime} 11.94^{\prime \prime} \mathrm{S}$ & $56^{\circ} 44^{\prime} 3 \cdot 52^{\prime \prime} \mathrm{W}$ & \\
\hline & San Pedro & Aguapey & & $24^{\circ} 31^{\prime} 26 \cdot 82^{\prime \prime S}$ & $56^{\circ} 47^{\prime} 9 \cdot 2^{\prime \prime} \mathrm{W}$ & \\
\hline \multirow[t]{4}{*}{ Bolivia } & Santa Cruz & San Antonio & & $20^{\circ} 1^{\prime} 1 \cdot 69^{\prime \prime} \mathrm{S}$ & $63^{\circ} 10^{\prime} 46 \cdot 32^{\prime \prime} \mathrm{W}$ & \\
\hline & Santa Cruz & Mora & & $18^{\circ} 27^{\prime} 25 \cdot 75^{\prime \prime} \mathrm{S}$ & $63^{\circ} 12^{\prime} 29 \cdot 47^{\prime \prime} \mathrm{W}$ & \\
\hline & Santa Cruz & Cuatro Cañadas & & $17^{\circ} 30^{\prime} 58 \cdot 302^{\prime \prime} \mathrm{S}$ & $61^{\circ} 35^{\prime} 58 \cdot 80^{\prime \prime} \mathrm{W}$ & \\
\hline & Santa Cruz & Gutierrez & & $19^{\circ} 26^{\prime} 10 \cdot 63^{\prime \prime S} \mathrm{~S}$ & $63^{\circ} 31^{\prime} 43 \cdot 65^{\prime \prime} \mathrm{W}$ & \\
\hline
\end{tabular}

Data from indigenous communities include: location, ethnic group and estimated population.

a Atlas de comunidades indígenas del Paraguay, http://www.dgeec.gov.py (2012). 
APPENDIX B

Table B1. Primers used and reaction conditions for each one of the PCR reactions performed

\begin{tabular}{|c|c|c|c|c|c|c|c|c|c|c|c|}
\hline \multirow[b]{2}{*}{$\begin{array}{l}\mathrm{PCR} \\
\text { reaction }\end{array}$} & \multirow[b]{2}{*}{$\begin{array}{l}\text { Primers sequence } \\
\left(5^{\prime}-3\right)\end{array}$} & \multicolumn{7}{|c|}{ Reaction mix ( $20 \mu \mathrm{L}$, total volume) } & \multirow[b]{2}{*}{ Reaction conditions } & \multirow[b]{2}{*}{$\begin{array}{l}\text { Electrophoretic } \\
\text { conditions }^{b}\end{array}$} & \multirow[b]{2}{*}{$\begin{array}{l}\text { Restriction } \\
\text { digestion } \\
\text { reaction }\end{array}$} \\
\hline & & $\mathrm{ddH}_{2} \mathrm{O}$ & $\begin{array}{l}\mathrm{NH}_{4} \\
\text { buffer } \\
(10 \times)\end{array}$ & $\begin{array}{l}\mathrm{MgCl}_{2} \\
(50 \mathrm{mM})\end{array}$ & $\begin{array}{l}\text { dNTP } \\
(2 \mathrm{mM})\end{array}$ & $\begin{array}{l}\text { Primer } \\
(20 \mathrm{pm} \\
\left.\mathrm{mL}^{-1}\right)\end{array}$ & $\begin{array}{l}\text { DNA } \\
\text { target }\end{array}$ & Taqpolymerase ${ }^{\mathrm{a}}$ & & & \\
\hline $\begin{array}{l}24 \mathrm{~S} \alpha \\
\mathrm{rRNA}\end{array}$ & $\begin{array}{l}\text { D71 AAG GTG } \\
\text { CGT CGA CAG } \\
\text { TGT GG } \\
\text { D72 TTT TCA GAA } \\
\text { TGGCCG AAC } \\
\text { AGT }\end{array}$ & $12 \cdot 2$ & 2 & $0 \cdot 6$ & 2 & 1 each one & 1 & $0 \cdot 2$ & $\begin{array}{l}30 \text { cycles: } 1 \text { min at } 94^{\circ} \mathrm{C} \text {, } \\
1 \text { min at } 60{ }^{\circ} \mathrm{C}, 1 \mathrm{~min} \text { at } \\
72{ }^{\circ} \mathrm{C} \\
1 \text { cycle: } 5 \text { min at } 72{ }^{\circ} \mathrm{C}\end{array}$ & $\begin{array}{l}80 \mathrm{~V} \\
0 \cdot 5 \times \text { TBE buffer } \\
3 \% \text { agarose } \\
2 \mathrm{~h} \\
\text { Hyperladder } 5 \\
\text { (Bioline) }\end{array}$ & \\
\hline $18 \mathrm{~S}$ rRNA & $\begin{array}{l}\text { V1 CAA GCGGCT } \\
\text { GGG TGG TTA } \\
\text { TTC CA } \\
\text { V2 TTG AGG GAA } \\
\text { GGC ATG ACA } \\
\text { CAT GT }\end{array}$ & $12 \cdot 2$ & 2 & $0 \cdot 6$ & 2 & 1 each one & 1 & $0 \cdot 2$ & Idem to $24 \mathrm{~S} \alpha \mathrm{rRNA}$ & $\begin{array}{l}\text { Idem to } 24 \mathrm{~S} \alpha \\
\text { rRNA }\end{array}$ & \\
\hline Mini-exon & $\begin{array}{l}\text { TC CCC CCC TCC } \\
\text { CAG GCC ACA } \\
\text { CTG } \\
\text { TC1 GTG TCC } \\
\text { GCCACC TCC } \\
\text { TTC GGG CC } \\
\text { TC2 CCT GCA } \\
\text { GGC ACA CGT } \\
\text { GTG TGT G }\end{array}$ & $11 \cdot 2$ & 2 & $0 \cdot 6$ & 2 & 1 each one & 1 & $0 \cdot 2$ & $\begin{array}{l}27 \text { cycles: } 30 \mathrm{~s} \text { at } 94^{\circ} \mathrm{C}, \\
30 \mathrm{~s} \text { at } 55^{\circ} \mathrm{C}, 30 \mathrm{~s} \text { at } \\
72{ }^{\circ} \mathrm{C} \\
1 \text { cycle: } 5 \mathrm{~min} \text { at } 72^{\circ} \mathrm{C}\end{array}$ & $\begin{array}{l}90 \mathrm{~V} \\
0 \cdot 5 \times \text { TBE buffer } \\
1 \cdot 5 \% \text { agarose } \\
90 \text { min } \\
\text { Hyperladder } 4 \\
\text { (Bioline) }\end{array}$ & \\
\hline $\begin{array}{l}\text { PCR- } \\
\text { RFLP of } \\
\text { HSP60 }\end{array}$ & $\begin{array}{l}\text { FWD GTG GTA } \\
\text { TGG GTG ACA } \\
\text { TGT AC } \\
\text { REV CGA GCA } \\
\text { GCA GAG CGA } \\
\text { AAC AT }\end{array}$ & 8 & 2 & 2 & 4 & 1 each one & 1 & $0 \cdot 2$ & $\begin{array}{l}30 \text { cycles: } 2 \mathrm{~min} \text { at } \\
94^{\circ} \mathrm{C}, 30 \mathrm{~s} \text { at } 94^{\circ} \mathrm{C}, \\
30 \mathrm{~s} \text { at } 60^{\circ} \mathrm{C}, 1 \mathrm{~min} \text { at } \\
72^{\circ} \mathrm{C} \\
1 \text { cycle: } 10 \mathrm{~min} \text { at } 72{ }^{\circ} \mathrm{C}\end{array}$ & $\begin{array}{l}90 \mathrm{~V} \\
0 \cdot 5 \times \text { TBE buffer } \\
1 \cdot 5 \% \text { agarose } \\
1 \mathrm{~h} \\
\text { Hyperladder } 4 \\
\text { (Bioline) }\end{array}$ & $\begin{array}{l}10 \mu \mathrm{L} \mathrm{PCR} \\
\text { product } \\
2 \mu \mathrm{L} 10 \times \text { buffer } \\
0 \cdot 2 \mu \mathrm{L} \mathrm{BSA}{ }^{\mathrm{c}} \\
0 \cdot 5 \mu \mathrm{L} \mathrm{EcoRV} \\
7 \cdot 3 \mu \mathrm{L} \mathrm{H} \mathrm{H}_{2} 0 \\
37^{\circ} \mathrm{C} \text { for } 4 \mathrm{~h}\end{array}$ \\
\hline
\end{tabular}

a Bioline Ltd. London, UK.

Stained with ethidium bromide and visualized under ultraviolet light.

c Bovine serum albumin acetylated $100 \times$ 